\title{
A. Appelmans* \\ Emhyteusis rights (long lease) and superficies rights (building rights) in the new Belgian Property Law
}

https://doi.org/10.1515/eplj-2021-0008

\section{Introduction}

1. The elasticity of ownership - The original Civil Code of 1804 did not provide for emphyteusis rights or building rights. The reason thereof was that these rights were, in the perspective of the post-Revolutionary legislator, too much of a threat for the newly created anti-feudal concept of ownership. In 1824 the Dutch legislator supplemented the French Civil Code of 1804 with two laws that fitted long leases and building rights into the legal framework of the United Kingdom of the Netherlands. Later on, both laws became an essential part of the Belgian property law framework and will now become part of the actual Civil Code. These two Dutch bills completed the limited list of property rights with, on the one hand, the long lease rights and, on the other hand, the building right. Both rights allow more elasticity for the right of ownership, and they contribute to the gradual hollowing out of ownership as the absolute gravitation point in property law.

2. Merging long lease and building rights - During the recent legislative process, there was a fundamental debate on whether two separate property rights were still needed. This mainly because superficies gradually evolved into a generic right, and, on top of that, an accessory building right is ipso iure attached to every emphyteusis. Nevertheless, the draft bill clearly explains that the legislator opted to keep the building right as a separate property right in the new code but with a clear intention to accentuate its specificities relative to long leases. ${ }^{1}$

1 Draft Bill inserting Book 3 "Goods" in the new Civil Code, Parl.Doc. Chamber, 2018-2019, nr. 543348/001, p. 331-332 (hereafter: Draft Bill, nr. 54-3348/001).

*Corresponding author: A. Appelmans, KU Leuven, Leuven,

E-Mail: alexander.appelmans@kuleuven.be 
In concreto, a superficies is a right of use, which entails a - generally temporary - division of the right of ownership (to immovable property) and thus confers a right to a volume. A right holder can erect buildings or plants on this volume. ${ }^{2}$ The actual power and ability to exercise this building right is the core of this property right. If there is no intention to build or plant, a building right should be requalified. A superficies concentrates specifically on the transfer of ownership: "Building and planting rights (...) give shape to the third dimension of property rights, by granting ownership of volumes on, over or under someone else's land, in whole or in part, as the case may be. All the rights and obligations of the parties are raised to this division of ownership." 3

\section{Long Lease Rights}

\section{A. Origin and fundamental principles of the new long lease right}

3. Revisions - In line with the new code's general objectives, the legislator intended to make long lease rights more functional, efficient and, above all, adapted to today's legal practice. While the rules have not substantially changed, there were some significant revisions, most notably regarding the minimum duration, the abolishment of the periodical canon and the accession compensation. In the case of long lease rights ${ }^{4}$ the new articles are listed under Title 7 of book 3 of the Belgian Civil Code (Art. 3.167-3.176 CC) ${ }^{5}$

4. Societal changes - Originally, the Roman long lease right aimed to solve the underuse of farmland. ${ }^{6}$ In 1804, the French Civil Code's drafters considered long leases an excessive burden on the right of ownership and, consequently, excluded them from the code. Their concern of hollowing out ownership was common in $19^{\text {th }}$ century post-Feudal Europe. However, during the subsequent Dutch period, long leases were re-established as a type of special contract. The law of January $10^{\text {th }} 1824$ tried to strike a balance between the risk of hollowing out the right of ownership and optimal use of land. While the 'agrarian' long lease fell into disuse after the industrialisation, we saw a revival in more recent

2 V. SAGAERT, 'De hervorming van het goederenrecht', TPR 2020, afl. 1, pp. 218-219.

3 Draft Bill, nr. 54-3348/001, p. 332 (own translation).

4 In French: "Droit d'emphythéose”, In Dutch: "Erfpachtrecht”.

5 Explanatory Memorandum of the Draft Statute, $\mathrm{n}^{\circ} .54-3348 / 001$, p. 262.

6 N. BERNARD, Le droit des biens: Après la réforme de 2020, Limal, Anthemis, 2020, pp. 717-718. 
times. $^{7}$ This revival replaced the agrarian use of long leases by an astute application of this property right in real estate development projects. Knowing this modern context, the Belgian legislator chose to promote flexibility and ex-ante legal certainty as central tenets of the revised long lease right. ${ }^{8}$

5. Definition - Article 3.167 CC gives an updated definition of the long lease: " $A$ long lease is a limited property right, which grants full use and enjoyment of immovable property of someone else. This property can be immovable by nature or by incorporation. A long leaseholder is prohibited from undertaking any actions that could lower the value of the real property. Except for devaluation due to normal use, age or force majeure. He can unless parties have agreed otherwise, change the purpose of the immovable property." The crucial difference between a long lease and the right of usufruct is the flexibility of a long leaseholder to change a property's purpose, except of course when otherwise agreed between the parties (Art. 3.167, $\S 2$ CC). A long lease is a far-reaching property right when it comes to use ${ }^{9}$ and enjoyment. ${ }^{10}$ Contrary to building rights, there is not necessarily a horizontal split in the case of long lease rights. Consequently, a long lease can be limited to a specific volume, which creates ample possibilities for a flexible application of the long lease right (see further below). ${ }^{11}$

6. Object - A long lease can be established on immovable property, in concreto land, subsoil or any type of constructions. ${ }^{12}$ There has long been a theoretical debate among Belgian legal scholars whether it is possible to establish a long lease on another property right. ${ }^{13}$ Current real estate projects often make use of this option. ${ }^{14}$ If we read Article 3.167 CC in conjunction with Article 3.168 CC, stating that any right of use holder can grant a lease right within the boundaries of their right (nemo plus), this legal controversy seems to be solved. The commentary

7 V. SAGAERT, B. TILLEMAN and A.L. VERBEKE, Vermogensrecht in kort bestek (zesde editie) in Recht in kort bestek, Mortsel, Intersentia, 2020, p. 381.

8 Draft Bill, nr. 54-3348/001, p. 312.

9 In French: "Usage”, In Dutch: “Gebruik”.

10 In French: "jouissance, In Dutch: “Genot”; V. SAGAERT, B. TILLEMAN, et al., Vermogensrecht in kort bestek (zesde editie) in Recht in kort bestek, Mortsel, Intersentia, 2020, p. 380.

11 J. BAECK and A. WYLLEMAN, Goederenrecht, Brugge, die Keure / la Charte, 2021, p. 142.

12 V. SAGAERT, 'De hervorming van het goederenrecht', supra vn. 2, para. 163; N. BERNARD, Le droit des biens: Après la réforme de 2020, Limal, Anthemis, 2020, p. 717.

13 For a list of pro and contra arguments see, V. SAGAERT and P. LECOCQ, De hervorming van het goederenrecht: Het ontwerp van de Commissie tot hervorming van het goederenrecht in De hervorming van het Burgerlijk Wetboek, Brugge, Die Keure, 2019, p. 352.

14 Explanatory Memorandum of the Draft Statute, $n^{\circ} .54-3348 / 001$, p. 317. 
in the draft bill states that with legal certainty in mind, it is now allowed for a long lease or building right holder to establish a sub-lease right, given that sub right is within the limitations of their own right. This sub right is then attached to the property itself, i.e., the original property's object, and not the right itself. ${ }^{15}$ As such, only physical goods can be the object of a long lease right.

7. Limitations - While the long lease is a flexible property right, parties are limited in two respects. Firstly, it is prohibited to denature the long lease as a property right. Parties have to respect the general economics and stability of a long lease. Otherwise, there is a risk of requalification as a sale when a contractual agreement deviates too much from a long lease contract's finality, i.e., the good's return into the landowner's assets. Secondly, parties have to respect the minimum (15 years) and maximum (99 years) duration of a long lease right (Art. 3.169 CC, see further on the rationale behind these durations below). ${ }^{16}$

8. Favourable tax regime - Next to its flexibility, another driver for using a long lease right is a favourable tax regime. Whereas the transfer of property rights, in the Flemish Region, is subject to a $10 \%$ registration fee, establishing a long lease is only subject to a $2 \%$ levy on the total fees. ${ }^{17} \mathrm{~A} 50$-year long lease with a (yearly) canon of $€ 500$ equals a $2 \%$ registration tax on $€ 25.000(500 \times 50)$ or $€ 500$. There are various anti-avoidance regulations in place to limit the purely fiscal use of a long lease.

9. Termination of a long lease - The right of long lease comes to an end following the general grounds for termination of Article 3.15 and $3.16 \mathrm{CC} .{ }^{18}$ As such, a grantor confronted with a non-performing leaseholder can claim the dissolution of the agreement. In the case of a contractual lease right, the grantor will often seek dissolution rather than a cancellation. In the case of a non-contractual long lease, dissolution is not possible, and a declaration of lapse will be the only option for the grantor. ${ }^{19}$ At the end of the long lease, any granted building rights terminate as well. Consequently, all buildings and plants become the grantor's

15 V. SAGAERT, 'De hervorming van het goederenrecht', supra vn. 2, para. 277.

16 V. SAGAERT, B. TILLEMAN, et al., Vermogensrecht in kort bestek (zesde editie) in Recht in kort bestek, Mortsel, Intersentia, 2020, pp. 380-381; J. BAECK and A. WYLLEMAN, Goederenrecht, Brugge, die Keure / la Charte, 2021, p. 143.

17 V. SAGAERT, B. TILLEMAN, et al., Vermogensrecht in kort bestek (zesde editie) in Recht in kort bestek, Mortsel, Intersentia, 2020, p. 382.

18 Ibid., p. 385.

19 V. SAGAERT, 'De hervorming van het goederenrecht', supra vn. 2, para. 285. 
property via accession, without the grantor being able to demand demolition. Generally, according to Article 3.174 CC, a landlord has to compensate a leaseholder for the construction and plantation works he carried out within the limits of his right, based on unjustified enrichment. Until the payment of this compensation, the leaseholder has a right to retain the constructions and plantations.

\section{B. Flexible duration of a long lease}

10. New time limitations - Article $3.169 \mathrm{CC}$ regulates the minimal and maximal duration of a long lease right. On the one hand, the new law shortens the minimum duration from 27 years to 15 years. Via this shortening, the legislator hoped to boost the practical relevance of the long lease right for modern real estate constructions, especially in real estate leasing. ${ }^{20}$ The legislator's explicit aim was to limit the use of building rights solely because a building right has a shorter minimum duration. However, according to the legislator, a specific minimum time buffer was required to provide economic stability and limit the risk of misappropriating a long lease as a workaround for the more protective regimes of rent (both commercial and private).

Nevertheless, parties can still mutually agree to terminate a long lease agreement before the end of the 15 years (Art. 3.174, § 2 CC). On the other hand, the maximum duration of a long lease contract remains unchanged, i.e. 99 years. Contracts for a longer duration are automatically reduced to 99 years.

11. Perpetual emphyteusis right - An emphyteusis right can now be perpetual (Art. 3.169, § 2 CC), but only in the limited hypothesis that the owner's right was established for public domain's purposes. This type of long lease can only be agreed upon by the actual owner and not by a use right holder. ${ }^{21}$ If the emphyteusis was established to erect buildings belonging to the public domain, its continuation should be possible as long as the public purpose is relevant, and the general interest continues to be pursued. However, in this case, the long leaseholder can terminate the emphyteusis if (1) either the buildings are disaffected from the public domain or (2) after more than 99 years the emphyteusis has lost all its utility, including future and potential (Art. 3.175 CC ). ${ }^{22}$

20 Explanatory Memorandum of the Draft Statute, $n^{\circ} .54-3348 / 001$, p. 318.

21 C. DE WULF, 'Inleiding tot het nieuwe goederenrecht', TNot. 2020, 2020, afl. 9, (690) p. 778.

22 V. SAGAERT, 'De hervorming van het goederenrecht', supra vn. 2, para. 279. 
12. Renewal vs. extension - The new law has, for the first time, made a clear distinction between the renewal and the extension of a property right. An extension of a long lease right is possible (1) if the original duration has not yet expired, (2) the total duration does not exceed the maximum duration of 99 years. An extension happens without accession. A renewal of a long lease happens with the explicit agreement of both parties. An implicit renewal is, as such, not possible. In the case of a renewal, a wholly new and separate long lease right is created. Consequently, this new right's maximum duration is 99 years and is not cumulated with any previous long lease rights. Unlike in the case of an extension, there will be accession, leading to both civil and tax consequences. ${ }^{23}$

13. Acquisitive prescription - In the case of acquisitive prescription, a long lease right is deemed to be established for 99 years, except when a legal act stipulates a shorter period. The lease right's duration starts at the onset of the valid possession or from a later point in time specified by the legal act (Art. 3.170 CC).

\section{The disappearance of the requirement of a periodical compensation}

14. Origin - Historically, there was the obligation for a right holder to pay a recurring compensation (canon, redevance). This fee was meant as a proof of the recognition of the existence of a right of ownership. As such, the fee amount did not have to reflect the actual value of the right to use the good, but it was merely an indication that the lease right holder recognised that he was not the actual owner of the property (un montant récognitif). ${ }^{24}$ However, since the introduction of reliable property registers, in the case of immovable property, specifically the mortgage register, the need for such a regular recognition has disappeared. ${ }^{25}$ Furthermore, parties would often bypass this obligation via symbolic canons and, on top of that, there was often an issue in the case of acquisitive prescription after thirty years without a title. ${ }^{26}$

23 Ibid., para. 280.

24 N. BERNARD, Le droit des biens: Après la réforme de 2020, Limal, Anthemis, 2020, p. 719.

25 V. SAGAERT and P. LECOCQ, De hervorming van het goederenrecht: Het ontwerp van de Commissie tot hervorming van het goederenrecht in De hervorming van het Burgerlijk Wetboek, Brugge, Die Keure, 2019, p. 350.

26 Explanatory Memorandum of the Draft Statute, $n^{\circ}$.54-3348/001, p. 314. 
15. Contractual freedom - Given that the practical relevance of a yearly canon seems to have disappeared, the legislator opted for flexibility and contractual freedom in the new regime. Under the new law, it will be possible to establish an emphyteusis free of charge, both when it is temporary and perpetual. ${ }^{27} \mathrm{~A}$ fortiori, therefore, it will be possible to establish a leasehold right for a one-off payment, payable at the beginning ('upfront') or the end of the leasehold right. ${ }^{28}$

\section{Flexibility for volume-properties}

16. Flexibility - Given that a long lease can be limited to a specific part of immovable property, it can be established on specific volumes above or below the ground. It can be limited to a building, without the actual surface on which it was built. This is an exemption to Article 3.8, § 2 CC and the unity principle in Belgian property law. ${ }^{29}$ Read in conjunction with the fact that a property right holder can establish a sub right (within the limits of their own right); there is a whole spectrum of flexible solutions for today's real estate practice. SAGAERT gives a telling example: a building right holder can establish a long lease on a building where he is the owner for the duration of his building right. This new long lease holder, who has an accessory building right on the ground on which the building stands, can, in turn, grant a long lease to a third person. ${ }^{30}$

17. Buildings erected by the leaser - A leaseholder can carry out all building and planting works, even if these change the real estate destination, provided that he does not reduce its value (Art. 3.172, par. 1 CC). The leaseholder is - temporarily and dependent - the owner of the buildings he erects or has erected during the leasehold period, and this based on his accessory building right. ${ }^{31}$

27 V. SAGAERT, B. TILLEMAN, et al., Vermogensrecht in kort bestek (zesde editie) in Recht in kort bestek, Mortsel, Intersentia, 2020, p. 384.

28 V. SAGAERT, 'De hervorming van het goederenrecht', supra vn. 2, para. 281.

29 In French: "principe d'unité", in Ducth: “eenheidsbeginsel”.

30 Ibid., para. 277.

31 Ibid., para. 283. 


\section{Building Rights}

\section{A. Origin and fundamental principles of the new building right}

18. Revisions - The new law aims to include all three dimensions of the physical world. The new Belgian Civil Code builds further on the earlier reform of the Building Rights Law of 2014. ${ }^{32}$ The new building right or superficies ${ }^{33}$ highlights specifically the third dimension of land, i.e. height and depth. Together, these three dimensions lead to the delineation of a volume, whether or not limited in height and depth (termed a special building right), as the object of this property right.

19. Economic importance - A building right is, similar to a long lease, a flexible property right which evolved out of an agrarian economy. Still, in today's society, it is of great economic importance. A typical example of a building rights' everyday use is when a company wants to invest in offices but prefers not to pay the land's purchase price. In this setup, they still aim for a legally secure solution. On the other hand, the owner of ground wants to have an economic return for his property but does not necessarily want to sell his ground. For these types of situations, a building right fits the bill perfectly. Another typical example is when a city gives a building right for a parking lot constructed by a private company. The right giver does not rent out his or her property and has minimal obligations compared to a rent agreement. ${ }^{34}$

20. Definition - Building (and planting) rights are a property right of use in rem which gives the right of ownership on volumes, whether built or not, in order to have buildings or plants thereon (Art. 3.177 CC; cf. former Art. 1 of the Act of January $10^{\text {th }} 1824$ on the right of superficies). The building right creates a - temporary - horizontal division of property, i.e., for the duration of the building right, the ownership of the land does not coincide with the ownership of the buildings, works and plantations which the holder of the right of superficies builds or acquires. Thus, the building right constitutes an exception to accession because the buildings, works and plantations do not connect to the land. Together with a deed in a flat joint ownership, which also excludes accession, building rights are the only way to deviate from the basic principle of accession..$^{35}$ Typical for superficies

32 Wet van 25 april 2014 houdende diverse bepalingen betreffende Justitie, BS 14 mei 2014.

33 In French: "droit de superficie”, in Dutch: "opstalrecht”.

34 J. BAECK and A. WYLLEMAN, Goederenrecht, Brugge, die Keure / la Charte, 2021, p. 135.

35 V. SAGAERT, B. TILLEMAN, et al., Vermogensrecht in kort bestek (zesde editie) in Recht in kort bestek, Mortsel, Intersentia, 2020, p. 387. 
is that it focuses on erecting buildings or plants rather than on the use and enjoyment. That does not mean, however, that a superficies right holder has no power over the volume.

21. Accessory vs. Independent building right - An independent building right is created - based on a legal act, the law or acquisitive prescription - with the sole purpose of a horizontal division of property. An accessory building right is a horizontal split that arises from another right of use, e.g., a long lease, that confers to a rightsholder the power to place buildings or plants on a particular immovable property (Art $3.182 \mathrm{CC}$ ). As such, an accessory building right arises out of the contractual or legal permission that a landowner gives to a third party to build on his or her land. ${ }^{36}$

There are three crucial differences between an accessory and an independent building right: ${ }^{37}$

(1) The duration: An independent building right is limited to 99 years while an accessory building right lasts as long as the primary right. That could even be perpetual if it is attached to an easement of overbuilding. ${ }^{38}$

(2) Right of disposal: an accessory right is closely connected to the personal or property right it is an accessory to. As such, it is not possible to detach it from that right, and it cannot be sold or mortgaged separately (Art. 3.182 CC).

(3) Compensation arrangement: The termination of an accessory building right is subject to the specific regulation for the termination of the primary right to which it is attached to (e.g. Art. 3.176 CC in the case of long leases).

22. The object of the superficies right - The object of a building right is, on the one hand, the ownership of the volume on which a right holder can erect buildings or plants and, on the other hand, the actual right to do so. As such, the building rights comes into existence immediately, even if there are no buildings erected (yet). The building or plants are not the object of the building right, but the result of exercising the building right. ${ }^{39}$

23. Subsoil building right - The new law further resolved an old legal debate. There was disagreement among legal scholars whether granting a superficies on an underground construction was permitted. Some scholars argued that the rules

36 Ibid., p. 388.

37 Ibid.

38 Cass. 12 June 2014, $\underline{R W} 2014-15,905$, note V. Sagaert.

39 V. SAGAERT, 'De hervorming van het goederenrecht', supra vn. 2, p. 223; C. DE WULF, 'Inleiding tot het nieuwe goederenrecht', supra vn. 19, p. 801. 
on building rights only cover the surface and not the subsoil. Consequently, they argued, it was possible to establish a perpetual property split in the subsoil outside of the Building Right Act. They deduced this, inter alia, from Article 553 of the old Civil Code, which stipulated that a third party can acquire the subsoil ownership by prescription. Since the 2014 Act, it has been clarified that both an aboveground and an underground property division fall under the scope of the right of superficies and are therefore subject to its term limitation. ${ }^{40}$

24. No building right on another property right - Under the new law, it is no longer possible to establish a superficies right on another right in rem. As such, building and planting rights can only relate to a specific immovable good, i.e. a volume. For today's legal practice, this does not have any negative consequences: a limited right holder can, within the limits and duration of its own right in rem, authorise a building lease (Art. 3.178 CC). Consequently, a long lease or usufruct holder can still grant a building right on the immovable property itself, within the limits of their own right, but not artificially on their own right. ${ }^{41}$

\section{B. Flexible duration}

25. Temporary right - Unlike long lease rights, there is no mandatory minimum duration for building and planting rights. That is one of the key reasons why they were often used as a more flexible alternative to emphyteusis. However, as explained above, the new Civil Code has reduced the minimum duration for a long lease, making this workaround unnecessary. Nevertheless, building and planting rights do have a maximum term. The new Civil Code has increased this maximum duration from 50 (Art. 4 Building Right Act) to 99 years (Art. 3.180 CC). If a superficies was contractually established for a more extended period (or even indefinitely), it is automatically converted into a building lease right of this statutory maximum duration. Unilateral options to extend or renew are also considered as unwritten. At the end of the building right's duration, the right holder can often claim compensation from the grantor, based on unjust enrichment (Art. 3.188 CC). ${ }^{42}$

40 V. SAGAERT, B. TILLEMAN, et al., Vermogensrecht in kort bestek (zesde editie) in Recht in kort bestek, Mortsel, Intersentia, 2020, p. 389.

41 V. SAGAERT, 'De hervorming van het goederenrecht', supra vn. 2, para. 293.

42 V. SAGAERT, B. TILLEMAN, et al., Vermogensrecht in kort bestek (zesde editie) in Recht in kort bestek, Mortsel, Intersentia, 2020, p. 394. 


\section{Stacking of volume-properties}

26. Perpetual building right - Since every renunciation of accession theoretically creates a building lease right, it is, in principle, impossible to carry out a perpetual horizontal property division. ${ }^{43}$ There are a few exceptions to this, however. The legislator has made it possible for a superficies right to be perpetual in three specific cases. These are deviations from the accession principle which creates a permanent, non-reversible horizontal split between a property volume and the rest of the (three-dimensional) land. Two of these three exceptions were already known under the old regime, namely (1) building rights in favour of public domain and (2) building rights that are accessory to an easement (Art. 3.180, par. $2 \mathrm{CC}$ ). The third exception is entirely new and offers substantial possibilities for the stacking of property rights. The perpetual building right was an attempt of the legislator to optimise the available space above and below the ground. It limits the risk of an anti-commons scenario. This reasoning was based on technical, economic and ecological grounds. ${ }^{44}$ The perpetual superficies risks limiting the elasticity of the ownership right. Thus, they are an essential exemption, next to, e.g. easements, to the gravitational force of ownership in Belgian property law. ${ }^{45}$

27. New possibilities in real estate development - The perpetual superficies right offers meaningful new opportunities for the Belgian real estate practice. As mentioned, they allow maximising the building volume of a plot of land and stack property volumes. A perpetual building right is the functional equivalent of a volume-property. This was also confirmed in the parliamentary preparations, in which the term 'volume property' is regularly used. ${ }^{46}$ Until this reform, it was only possible for developers to artificially deviate from the accession principle via either the regime of co-ownership or by creating a right to overbuild with ancillary building rights. ${ }^{47}$ The critical difference between a right of ownership and a perpetual building right is that a building right is still subject to liberating prescription if it is not used for more than 30 years, while a right of ownership is not.

43 Ibid., pp. 389-390.

44 Explanatory Memorandum of the Draft Statute, $n^{\circ} .54-3348 / 001$, p. 339.

45 V. SAGAERT, 'De hervorming van het goederenrecht', supra vn. 2, para. 300.

46 Parl. St. Kamer 2019-20, nr. 173/4, 68; Ibid., para. 299.

47 Explanatory Memorandum of the Draft Statute, $n^{\circ} .54-3348 / 001$, p. 330. 
Reproduced with permission of copyright owner.

Further reproduction prohibited without permission. 